\title{
Article \\ Evaluation of Behavioral Changes and Tissue Damages in Common Carp (Cyprinus carpio) after Exposure to the Herbicide Glyphosate
}

\author{
Ahmad Mohamadi Yalsuyi ${ }^{1}$ (D), Mohammad Forouhar Vajargah ${ }^{2}$, Abdolmajid Hajimoradloo ${ }^{1}$, \\ Mohsen Mohammadi Galangash ${ }^{3}$, Marko D. Prokić ${ }^{4}(\mathbb{D})$ and Caterina Faggio $^{5, *(\mathbb{D})}$ \\ 1 Department of Aquaculture, Faculty of Fisheries and Environment, Gorgan University of Agricultural \\ Sciences and Natural Resources, Gorgan 4913815739, Iran; ahmad_m.yalsuyi@yahoo.com (A.M.Y.); \\ A_hajimoradloo@gau.ac.ir (A.H.) \\ 2 Department of Fisheries, Faculty of Natural Resources, University of Guilan, Sowmehsara 4199613776, Iran; \\ Mohammad.forouhar@yahoo.com \\ 3 Department of Environmental Sciences and Engineering, Faculty of Natural Resources, University of Guilan, \\ Sowmehsara 4199613776, Iran; m_mohammadi@guilan.ac.ir \\ 4 Department of Physiology, Institute for Biological Research "Siniša Stanković", National Institute of Republic \\ of Serbia, University of Belgrade, 11060 Belgrade, Serbia; marko.prokic@ibiss.bg.ac.rs \\ 5 Department of Chemical, Biological, Pharmaceutical and Environmental Sciences University of Messina, \\ 98122 Messina, Italy \\ * Correspondence: cfaggio@unime.it
}

\section{check for} updates

Citation: Yalsuyi, A.M.; Vajargah, M.F.; Hajimoradloo, A.; Galangash, M.M.; Prokić, M.D.; Faggio, C. Evaluation of Behavioral Changes and Tissue Damages in Common Carp (Cyprinus carpio) after Exposure to the Herbicide Glyphosate. Vet. Sci. 2021, 8, 218. https://doi.org/ $10.3390 /$ vetsci 8100218

Academic Editors: Kartik Baruah and Patrick Butaye

Received: 20 August 2021

Accepted: 2 October 2021

Published: 5 October 2021

Publisher's Note: MDPI stays neutral with regard to jurisdictional claims in published maps and institutional affiliations.

Copyright: (c) 2021 by the authors. Licensee MDPI, Basel, Switzerland. This article is an open access article distributed under the terms and conditions of the Creative Commons Attribution (CC BY) license (https:// creativecommons.org/licenses/by/ $4.0 /)$.

\begin{abstract}
Pesticides can induce changes in behavior and reduce the survival chance of aquatic organisms. In this study, the toxic effects of glyphosate suspension (Glyphosate Aria 41\% SL, Tehran Iran) on behavior and tissues of common carp (Cyprinus carpio) were assessed. For this purpose, a $96 \mathrm{~h} \mathrm{LC}_{50}$ of glyphosate suspension $\left(68.788 \mathrm{~mL} \cdot \mathrm{L}^{-1}\right)$ was used in the toxicity test. All individuals were divided into control and treatment groups with four replicates. Exposure operations were performed under two conditions: increasing concentration of suspension from 0 to $68.788 \mathrm{~mL} \cdot \mathrm{L}^{-1}$; then, decreasing to the first level. The swimming pattern was recorded by digital cameras during the test and tissue samples were collected at the end of the test. There were significant differences between the swimming pattern of treated individuals and control ones during both steps. The sublethal concentration of glyphosate led to hypertrophy, hyperplasia and hyperemia in the gill of fish. However, changes were obvious only after sampling. The exposed fish also displayed clinical signs such as darkening of the skin and increasing movement of the operculum. Moreover, glyphosate suspension affected swimming patterns of fish suggest that the swimming behavior test can indicate the potential toxicity of environmental pollutants and be used as a noninvasive, useful method for managing environmental changes and assessing fish health conditions by video monitoring.
\end{abstract}

Keywords: acute stress; glyphosate; behavioral responses; tissue damages; Cyprinus carpio

\section{Introduction}

The projection is that the world population will excess seven billion people and will reach nine billion by 2050 [1]. Population growth will overcome agriculture product growth by 2030. A series of factors (land degradation, falling cropland per person, global climate change, water crisis, uneven distribution of resources and reduced yields per hectare) in some continents and areas (i.e., Africa and west Asia) of the world already threaten human food safety [2-4]. Plant pests are one of the important contributing factors in reducing agriculture production. Global statistics show that an average of $35 \%$ of agricultural products is lost due to the effects of preharvest pests [5,6]. However, the use of pesticides appears to become less effective on crop pests [5]. As an example, Raven et al. [7] showed that even though agriculture production and use of pesticides significantly increased (about 
$33 \%$ ) after the 1940s in the USA, the percent of agricultural waste lost because of pests has not changed significantly. The fold increase went up to 15-20 in recent years $[5,8]$ and the total annual cost spent by farmers to supply and buy pesticides is about USD 40 billion [9]. It was observed that pesticides near the target organism, affect a large number of the nontarget organisms. These effects are not limited only to the death of the nontarget organisms, but are also linked to changes in organism fitness (reproduction, survival and longevity) [10-16]. Environmental pollutants can affect behavior and life history parameters including growth and reproductive functions of nontarget organisms. Thus, there are serious concerns about the increased use of pesticides as a way to increase crop yield [17-19].

Among herbicides, glyphosate $\left(\mathrm{C}_{3} \mathrm{H}_{8} \mathrm{NO}_{5} \mathrm{P}-41 \% \mathrm{SL}\right)$ is one of the most commonly used. In recent years, due to its impressive effect on weeds, the use of glyphosate has rapidly increased worldwide, especially in developing countries [20,21]. Glyphosate is sold in over 100 countries and its global use reached more than 800,000 tons in 2014 [22]. It is a type of herbicide that displays an effect on the activity of 5-enolpyruvylshikimate3-phosphate synthase (EPSP) and inhibits or impairs the synthesis of aromatic amino acids in plant cellulose [20,23]. Aquatic environments are often the last destination for this pollutant [24-26], and due to its high solubility and relatively long half-life, it is usually present in water ecosystems. It leaches into water through several routes such as rainfall, river and soil erosion [27]. The growing trend in its usage has led to an increase in residues and adverse effects of this herbicide on biotic and abiotic components of the ecosystems [28]. The results of previous studies pointed out that glyphosate can be toxic to nontarget organisms. Evans et al. [16] studied the toxicity effect of glyphosate-based herbicides on the behavior and survival rate of nontarget organisms (spiders and ground beetles). Results of their study showed that glyphosate suspension, apart from affecting arthropod community dynamics, can significantly change behavior (prey behavior) and reduced the survival chance of spiders and ground beetles. In this study we used the common carp (Cyprinus carpio) as a model organism. Exposure of the common carp to glyphosate can reduce the rate and survival chance [29-32].

There are various methods to evaluate the possible toxicity of the pesticide. Most of them require sacrificing a great number of individuals, especially for the $\mathrm{LC}_{50} 96 \mathrm{~h}$ test, which is based on finding the lethal concentration that kills half of the population [18]. Histopathological testing on the other hand has some limitations, such as: time-consuming processes for sampling, fixation and preparing of tissue sections; need to use different chemical substance and relatively expensive tools [33]. Behavioral tests are a noninvasive method for evaluation of adverse effects of stressor parameters and do not require killing fish or the use of expensive tools $[34,35]$. Behavior is the result of the interaction between internal and external stimuli [36]. Hence, behavioral studies are based on behavioral changes of the organism that are exposed to a wide range of stressor parameters such as pollutants, prey, hunter, acute or chronic changes of water physicochemical parameters and pathogens [37,38]. Finally, this type of studies can provide useful and new information about the effects of pollutants on an organism that could not be found with other methods [36,39].

The present study aims to evaluate behavioral changes and tissue damages of common carp (Cyprinus carpio) exposed to sublethal and lethal concentrations of glyphosate. We also investigate the possible use of the swimming pattern of fish as a behavior parameter in toxicological studies and environmental quality assessment [34].

\section{Materials and Methods}

All steps of the present study were performed according to ethical standards and valid regulations. The protocol of the study was according to guidelines issued by the Gorgan University of Agricultural Sciences and Natural Resources Research Ethics Committee (No. IR-GAUEC207s-2020). 


\subsection{Preparing}

For the experimental procedure, 100 fingering common carp (Cyprinus carpio) with an average weight of $4.85 \pm 0.6 \mathrm{~g}$ were bought and transferred to the research center (laboratory of the Faculty of Natural Resources, University of Guilan, Guilan province, Iran) The fish were randomly divided into 4 tanks ( $250 \mathrm{~L}-25$ fish in each tank). In order to adapt to the laboratory conditions, the fish were maintained in these tanks for 2 weeks. They were fed a commercial diet (produced by Faradaneh Co., Tehran, Iran) at 3\% of biomass weight, twice a day, during the adaptation period. Physicochemical parameters of water were measured every day and they were the same in all tanks ( $\mathrm{pH}$ 6.7-7.4, temperature $25 \pm 1{ }^{\circ} \mathrm{C}$, DO $8 \mathrm{mg} \cdot \mathrm{L}^{-1}, \mathrm{NH}_{3}<0.02 \mathrm{mg} \cdot \mathrm{L}^{-1}$ and total hardness $185 \mathrm{mg} \mathrm{CaCO}$ ). The $\mathrm{pH}$ and temperature, dissolved oxygen (DO), $\mathrm{NH}_{3}$ concentration and total hardness of water $\left(\mathrm{CaCO}_{3}\right.$ concentration) were measured by a digital soil and substrate $\mathrm{pH}$ meter (S500 pro, Aqua Masters, Burbank, CA, USA), a dissolved oxygen meter for aquaculture (HI9147, HANNA Instruments, Bertoki, Slovenia) and multiparameter photometers (7100, Palintest Co., Gateshead, UK) twice a day, respectively.

\subsection{Toxicity Test}

According to Vajargah et al. [8] and Hedayati et al. [18], after the adaptation period, 60 fingerling fish (average of weight $4.85 \pm 0.62 \mathrm{~g}$ ) were divided into 4 groups with 3 replicates (12 aquariums $100 \times 40 \times 50 \mathrm{~cm}$ ) and exposed to 4 concentrations of commercial formulation of glyphosate suspension (glyphosate Aria 41\% SL, Tehran, Iran). Nominal concentrations of glyphosate were $0,50,100$ and $150 \mathrm{~mL} \cdot \mathrm{L}^{-1}$ and the test duration was $96 \mathrm{~h}$. The fish mortality rate was calculated at $24,48,72$ and $96 \mathrm{~h}$ after exposure. Fish were transferred into the test tank $16 \mathrm{~h}$ before beginning the test and they did not feed during the toxicity test. Water physicochemical parameters were kept the same as one of the adaptation periods ( $\mathrm{pH}$ 6.7-7.4, temperature $25 \pm 1{ }^{\circ} \mathrm{C}$, DO $8 \mathrm{mg} \cdot \mathrm{L}^{-1}, \mathrm{NH}_{3}<0.02 \mathrm{mg} \cdot \mathrm{L}^{-1}$ and total hardness $185 \mathrm{mg} \mathrm{CaCO}$ ). The $\mathrm{LC}_{50} 96 \mathrm{~h}$ test was a static system. Finally, glyphosate concentrations were added manually and the pesticide was distributed by water circulation inside the aquarium.

\subsection{Histopathological Test}

The gill samples of fish were collected at 24, 48, 72 and $96 \mathrm{~h}$ after exposing the fish to glyphosate (one sample for each replication) and they were fixed by diluted Formalin solution (Formaldehyde $10 \% v / v$, Sigma ${ }^{\circledR}$, St. Louis, MO, USA). Formalin of the gill samples was replaced $24 \mathrm{~h}$ after sampling [8]. The second gill arch from the fish's left side was selected for sampling. The samples were placed in a series of alcohols (50, 70, 80 and $96 \%$ ) for half an hour. Immediately after that, the gill sample was washed with 1-butanol alcohol (for $2 \mathrm{~h}$ ) and then they were placed into chloroform for clarifying for $1 \mathrm{~h}$. After this step, the gill samples were placed into an incubator at $37^{\circ} \mathrm{C}$ for paraffinization and softening using a solution of chloroform and paraffin (1:1). Then, samples were incubated in pure paraffin at $54{ }^{\circ} \mathrm{C}$ and were prepared for tissue incisions after cooling. The tissue incisions were obtained with an automatic tissue processor machine (TP1020, Leica Microsystems Inc., Buffalo Grove, IL, USA) and their thickness was $6 \mu \mathrm{m}$. The tissues incisions were stained by hematoxylin-eosin [33]. Tissue damages were observed and evaluated by light microscopy (Model RH-85 UXL, UNILAB ${ }^{\circledR}$, Mumbai, India). Organ damages were analyzed according to Vajagah et al. [8] and compared with each other.

\subsection{Behavioral Test}

According to Kang et al. [34] and Kane et al. [36], after measurement of the $96 \mathrm{~h} \mathrm{LC}_{50}$ of the glyphosate suspension (glyphosate Aria $41 \%$ SL, Tehran, Iran) the behavior test was performed. The selection of fish was based on a completely random design, namely: 8 fingering common carp (Cyprinus carpio) with an average weight of $5.93 \pm 0.8 \mathrm{~g}$ were selected and divided into 2 groups (control and glyphosate treatment) with 4 repetitions and maintained in 8 test tanks (the volume of water was $5 \mathrm{~L}$ in the test tank, one fish in each 
tank). Fishes were transferred into the test tanks $12 \mathrm{~h}$ before beginning the behavior test for adaptation and were not feed during the behavioral test. The test tanks had a water inlet and an outlet, and the water flow rate was the same in these tanks. The rate of water flow was chosen so that the nominal concentration of the commercial formulation of glyphosate could reach $96 \mathrm{~h} \mathrm{LC}_{50}$ at $12 \mathrm{~h}$. The water flow rate was $416.667 \mathrm{~mL} \cdot \mathrm{h}^{-1}$. For the glyphosate treatment, the nominal concentration of suspension was increased from $0 \mathrm{~mL} \cdot \mathrm{L}^{-1}$ to the $96 \mathrm{~h} \mathrm{LC}_{50}$ during the first step (12 h). Finally, in order to evaluate behavioral responses of fish to a return or improvement of environmental parameters, the nominal concentration of suspension was reduced from the $96 \mathrm{~h} \mathrm{LC} 50$ to $0 \mathrm{~mL} \cdot \mathrm{1}^{-1}(12 \mathrm{~h})$ during the second step (Figure 1b). The water flow rate of the control group tank was similar to the glyphosate treatment. In addition, water physicochemical parameters were similar to the adaptation period ( $\mathrm{pH} 6.7-7.4$, temperature $25 \pm 1{ }^{\circ} \mathrm{C}$, DO $8 \mathrm{mg} \cdot \mathrm{L}^{-1}, \mathrm{NH}_{3}<0.02 \mathrm{mg} \cdot \mathrm{L}^{-1}$ and total hardness $185 \mathrm{mg} \mathrm{CaCO}_{3}$ ). The nominal concentration of the commercial formulation of glyphosate was $0 \mathrm{~mL} \cdot \mathrm{L}^{-1}$ during both steps of the behavioral test. The water flow and the glyphosate concentration were maintained constant during the test by adjustable valves and a mixer and a precision pump (BT300-2J medium flow rate peristaltic pump, Longer Precision Pump Co., Ltd., Baoding, China), respectively. The water surface was fixed in the test tanks and water physicochemical parameters were checked every 6 h. Finally, all of the analyses were conducted in one day.

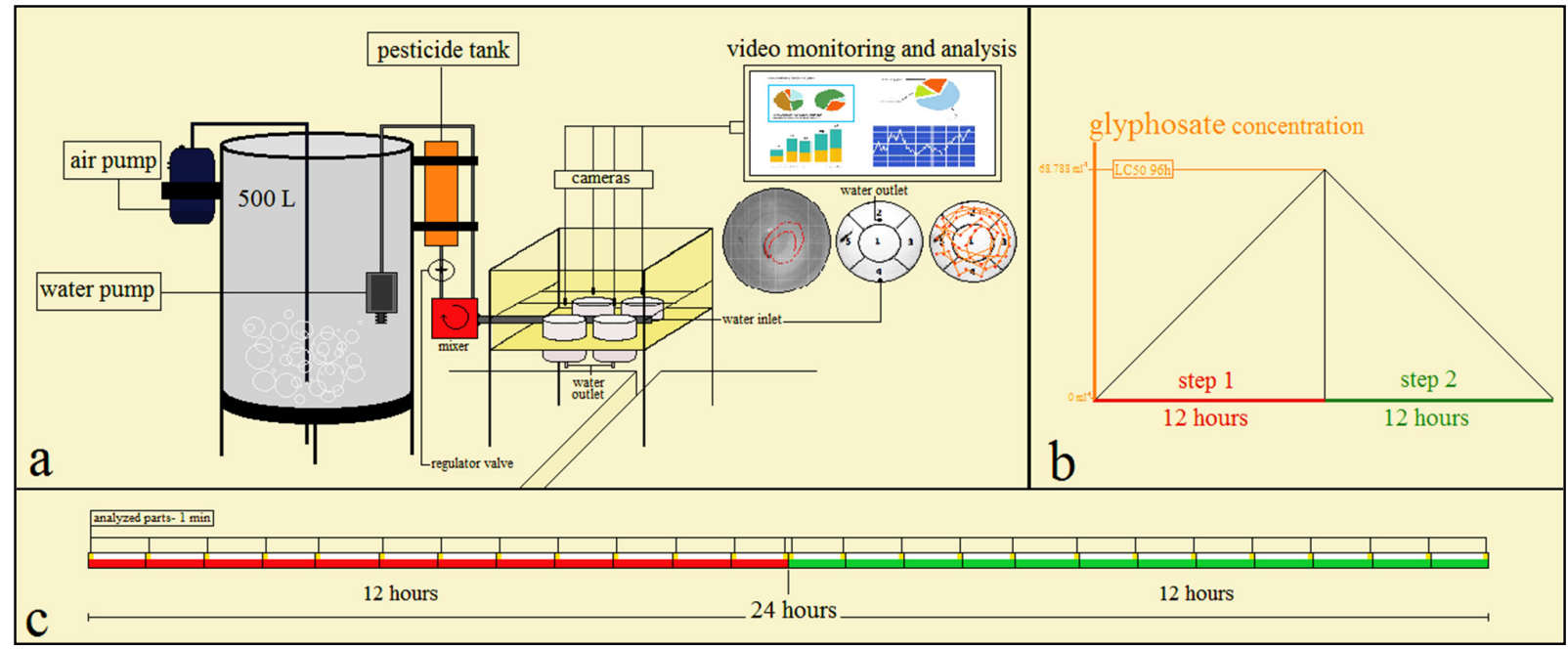

Figure 1. Schematic description of the test environment and its stages. (a) System design and components of the test. (b) Steps of the test; concentration of glyphosate suspension was increased and reached the $96 \mathrm{~h} \mathrm{LC} 50$ during step 1 , then was decreased and reached $0 \mathrm{~mL} \cdot \mathrm{L}^{-1}$ during step 2. (c) The timeline of the behavioral test: each step was $12 \mathrm{~h}$ and there were 26 time points. The behavior test was a dynamic test. The fish swimming was recorded at these time points of 1 min duration. The water flow during the test was $416.667 \mathrm{~mL} \cdot \mathrm{h}^{-1}$.

The swimming patterns of fish were recorded by 8 digital cameras (Canon, SX230 Hs, 5.0-70 mm) at 26 time points, 1 min apart (Figure 1c). Each camera was on top of a test tank (Figure 1a). The height of the cameras was $10 \mathrm{~cm}$ from the water surface. The total time of the recording parts for each fish was $26 \mathrm{~min}$ (26 separate 1 min pieces) and their format was MP4 (.mp4)

\subsection{Data Analysis}

The lethal concentration of glyphosate at intervals of $24,48,72$ and $96 \mathrm{~h}(24 \mathrm{~h}, 48 \mathrm{~h}, 72 \mathrm{~h}$ and $96 \mathrm{~h} \mathrm{LC}_{50}$ of glyphosate) were estimated through probit tests with a $95 \%$ confidence. To find the correlation between different nominal concentrations of commercial formulations of glyphosate and mortality we used a Spearman test (2-tail).

The video data were analyzed by Adobe After Effects software (AAE CS6) on a Windows platform (Windows 7 Ultimate, Microsoft corporation $₫$, Redmond, WA, USA). 
This software program converted selected video data (resolution $640 \times 480,30$ frames per second) to 1 frame per second and indicated the position of the fish in each frame through the location of the fish head (Figure 1a). The output file format of this software was a FLV video file (.flv). The total movement and distance from the center in different sections were measured by Digimizer (Version 4.6.1, MedCalc Software, Ostend, Belgium) on a Windows platform [40]. The differences between average measured indicators of treatment at different concentrations and the control group were calculated through a LSD test with a 95\% confidence by SPSS software (SPSS Statistics 20, IBM, Armonk, NY, USA). Finally, the correlations between swimming parameters were checked with Pearson's and Spearman's two-tailed significance tests using SPSS software (SPSS Statistics 20, IBM).

The clinical signs of fish were reported by direct observation of recorded videos, counting of the average movements of the gill operculum in $1 \mathrm{~min}$ and a comparison of the color of the object (fish) for a period of time by Adobe After Effects software (AAE CS6, Adobe Co., Mountain View, CA, USA).

Behavioral changes of fish were characterized through the analysis of the average swimming speed (A.S.), total movement (T.M.), percent movement (P.M.), fastest movement (F.M.), average angular change of movement (A.C.) and the average distance from the center (D.C.); these parameters of swimming patterns were selected and modified according to Kane et al. [37] and Yalsuyi et al. [40] (Table 1).

Table 1. Parameters of swimming patterns of fish, that are used in the present study as characteristics of behavioral responses of common carp (Cyprinus carpio) exposed to acute changes of environmental parameters (ammonia and temperature).

\begin{tabular}{|c|c|}
\hline Swimming Pattern Parameters & Definition \\
\hline Average speed swimming (A.S.) & $\begin{array}{l}\text { The average speed of the fish in } t \text { seconds, when the fish move to } X \mathrm{~cm} \\
\qquad\left(\bar{V}=\frac{\left(x_{1}+x_{2}+x_{3}+\ldots .+x_{t}\right)}{t}\right)\end{array}$ \\
\hline Total movement (T.M.) & $\begin{array}{l}\text { Total movement of the fish in } t \text { seconds: } \\
X_{T}=t\left(\left(x_{1} v_{1}\right)+\left(x_{2} v_{2}\right)+\left(x_{3} v_{3}\right)+\ldots+\left(x_{t} v_{t}\right)\right) \text {. The movement is the } \\
\text { displacement of the fish body by about two-thirds of their body length }\end{array}$ \\
\hline Percent movement (P.M.) & $\begin{array}{l}\text { Percent of movement is total movement time }(t) \text { to total time }(T) \text { multiply by } 100 \\
\qquad\left(\text { P.M }=\frac{t}{T} \times 100\right)\end{array}$ \\
\hline Fastest movement (F.M.) & $\begin{array}{c}\text { The total distance that fish in that time }(1 \mathrm{~s}) \text { has more than double the average } \\
\text { swimming speed. }\end{array}$ \\
\hline Average angular change of movement (A.C.) & The angle differences from points $t_{2}$ to $t_{1}$ when the point $t_{0}$ is beginning to move. \\
\hline Average distance from the center (D.C.) & $\begin{array}{l}\text { Average distance of specific region of fish (i.e., fish head) from the center of the test } \\
\text { tank in } t \text { time. }\end{array}$ \\
\hline
\end{tabular}

Note: all parameters were selected according to Kane et al. [37] and modified.

\section{Results}

\subsection{Results of the $96 \mathrm{hLC}_{50}$ (Lethal Concentration of $50 \%$ of the Population in $96 \mathrm{~h}$ ) Test}

No mortality of fish was observed during the adaptation period. The results of the toxicity test showed that there was a significant correlation between the mortality rate of fish and the concentration of the commercial formulation of glyphosate $(p<0.01)$. Mortality was observed in all treatment steps (except for the control group at $0 \mathrm{~mL} \cdot 1^{-1}$ of glyphosate) and there were significant differences between mortality rates and treatment levels $(p<0.01)$. The $96 \mathrm{~h} \mathrm{LC}_{50}$ of commercial formulation of glyphosate was $68.788 \mathrm{~mL} \cdot \mathrm{L}^{-1}$ and its 24,48 and $72 \mathrm{~h} \mathrm{LC} 50$ were 202.132, 130.014 and $92.798 \mathrm{~mL} \cdot \mathrm{L}^{-1}$, respectively. According to the results of the test of homogeneity of variance (Levene's Test), we did not observe significant differences between the variance of groups $(p>0.05)$.

\section{Results of the Histopathological Assay}

We did not find any significant tissue damages in the control group. Damages were observed in all treatments of glyphosate $\left(50,100\right.$ and $\left.150 \mathrm{~mL} \cdot \mathrm{L}^{-1}\right)$ at $96 \mathrm{~h}$ after exposure. There were significant correlations between tissue damages and glyphosate concentrations $(p<0.05)$. The tissue damages including hyperemia, hypertrophy, hyperplasia, secondary 
lamellar adhesion, hemorrhage and necrosis were found in gill samples of fish that were exposed to sublethal and lethal concentrations of glyphosate (Table 2). The highest damages of gills were reported at $150 \mathrm{~mL} \cdot \mathrm{L}^{-1}$ of glyphosate. The gills hyperplasia (HP), hypertrophy (HT), swollen primary gill (SPG), secondary lamellar adhesion (SLA), hyperemia (H), hemorrhage (HR) and necrosis (N) were clearly observed in the samples (Figure 2).

Table 2. Gill damages in common carp (Cyprinus carpio) after $96 \mathrm{~h}$ exposure to commercial formulation of glyphosate (glyphosate Aria $41 \% \mathrm{SL}$ - suspension).

\begin{tabular}{ccccc}
\hline & \multicolumn{4}{c}{ Nominal Concentrations $\left(\mathbf{m L} \cdot \mathbf{L}^{-\mathbf{1}}\right)$} \\
\hline Tissue Damages & $\mathbf{0}$ & $\mathbf{5 0}$ & $\mathbf{1 0 0}$ & $\mathbf{1 5 0}$ \\
\hline Hyperemia & - & ++ & +++ & +++ \\
Hyperplasia & - & +++ & +++ & +++ \\
Hypertrophy & - & ++ & ++++ & ++++ \\
Swollen primary gill & - & ++ & +++ & +++ \\
Secondary lamellar adhesion & - & +++ & +++ & ++++ \\
Hemorrhage & - & ++ & ++ & +++ \\
Necrosis & - & + & +++ & ++++ \\
\hline
\end{tabular}

(-) No gill tissue damage could be seen; (+) there were gill tissue damages from 1 to $3 ;(++)$ there were gill tissue damages from 3 to $5 ;(+++)$ there were gill tissue damages from 5 to $9 ;(++++)$ there were gill tissue damages from 9 to 15 .

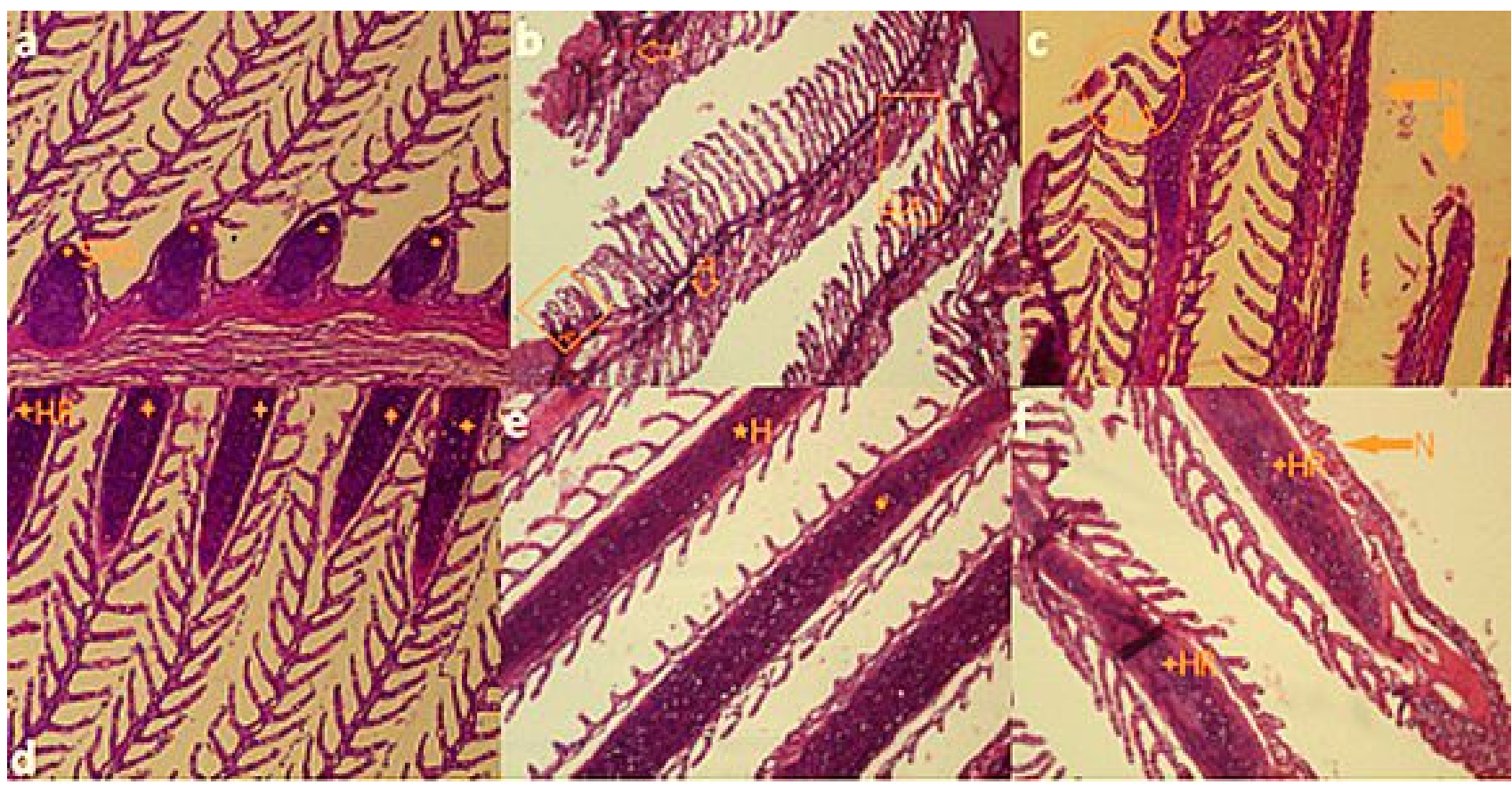

Figure 2. Photomicrographs of common carp (C. carpio) after $96 \mathrm{~h}$ exposure to lethal concentrations of commercial formulation of glyphosate (glyphosate Aria $41 \%$ SL suspension): (a) swollen primary gill (SPG) in $50 \mathrm{~mL} \cdot \mathrm{L}^{-1}$; (b) hyperplasia (HP), hypertrophy (HT), secondary lamellar adhesion (SLA) and necrosis (N) of gills in $100 \mathrm{~mL} \cdot 1^{-1}$; (c) secondary lamellar adhesion (SLA) and necrosis (N) of gills in $150 \mathrm{~mL} \cdot \mathrm{L}^{-1}$; (d,e) hemorrhage (HR) and hyperemia (H) in 100 and $150 \mathrm{~mL} \cdot \mathrm{L}^{-1}$, respectively; (f) hemorrhage $(\mathrm{HR})$ and necrosis $(\mathrm{N})$ of gills in $150 \mathrm{~mL} \cdot \mathrm{L}^{-1}$. All pictures are magnified $\times 10$.

The primary tissue damages were seen $24 \mathrm{~h}$ after exposure and they intensified during the $96 \mathrm{~h} \mathrm{LC}_{50}$ test. Finally, we did not see or record any significant tissue damages in the control group (concentration $0 \mathrm{~mL} \cdot \mathrm{L}^{-1}$ of glyphosate suspension). The results of the histopathological assay of the gills are shown in Table 2. 


\subsection{Results of the Behavioral Assay \\ 3.2.1. Control Group}

We did not record any mortality in the glyphosate treatment and control groups during the behavioral test. There was a significant correlation between average swimming speeds and total movements $(p<0.01)$. However, there were no significant correlations between these parameters and other swimming parameters $(p>0.05)$. In addition, there were no significant differences between swimming parameters at different time points and the test steps (Figure 3). Finally, no significant differences between the swimming patterns of the control group fish during the test steps were observed (Table 3).

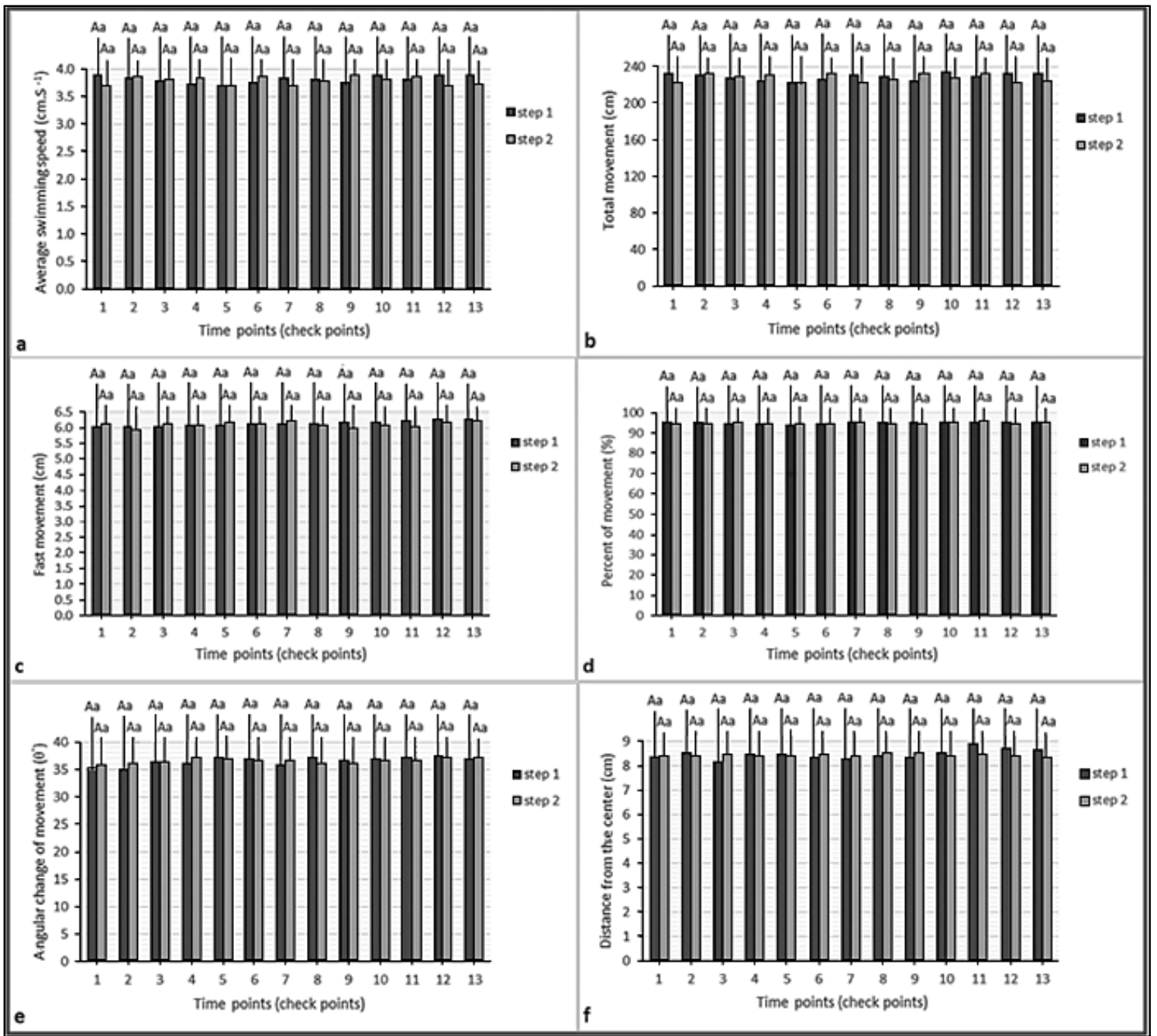

Figure 3. Parameters of swimming pattern of the fish in the control group: (a) average speed; (b) total movement; (c) fast movement; (d) percent of movement; (e) average angular change of movement; (f) distance from the center. Similar lowercase letters (a) indicate nonsignificant differences between values of the same color columns $(p>0.05)$. Similar uppercase letters (A) indicate nonsignificant differences between values of paired columns $(p>0.05)$.

The results showed that fish rarely changed their swimming directions and they were swimming near the middle of the test tanks in a circular path during the test (Figure 4a). The area of the test tank was $660.185 \mathrm{~cm}^{2}$ and the total movement of the fish in $1 \mathrm{~min}$ was usually less than half of the area of the test tanks. 
Table 3. Comparison of the average of swimming parameters of different groups in all the different steps of the test. Parameters were average swimming speed (A.S.), total movement (T.M.), percent movement (P.M.), fastest movement (F.M.), average angular changes of movement (A.C.) and the average distance from the center (D.C.).

\begin{tabular}{ccccc}
\hline & \multicolumn{4}{c}{ The Test Groups } \\
\cline { 2 - 5 } Parameters & \multicolumn{2}{c}{ Control Group } & \multicolumn{2}{c}{ Glyphosate Treatment } \\
\cline { 2 - 5 } & Step 1 & Step 2 & Step 1 & Step 2 \\
\hline A.S. $\left(\mathrm{cm} \cdot \mathrm{s}^{-1}\right)$ & $3.82 \pm 0.02^{\mathrm{b}}$ & $3.79 \pm 0.02^{\mathrm{b}}$ & $4.85 \pm 0.18^{\mathrm{a}}$ & $5.06 \pm 0.05^{\mathrm{a}}$ \\
T.M. $(\mathrm{cm})$ & $228.84 \pm 1.08^{\mathrm{b}}$ & $227.31 \pm 1.26^{\mathrm{b}}$ & $290.87 \pm 10.85^{\mathrm{a}}$ & $303.39 \pm 3.29^{\mathrm{a}}$ \\
P.M. $(\%)$ & $95.25 \pm 0.16^{\mathrm{b}}$ & $95.06 \pm 0.12^{\mathrm{b}}$ & $96.38 \pm 0.21^{\mathrm{a}}$ & $96.10 \pm 0.46^{\mathrm{a}}$ \\
F.M. $(\mathrm{cm})$ & $6.14 \pm 0.02^{\mathrm{b}}$ & $6.11 \pm 0.02^{\mathrm{b}}$ & $14.40 \pm 0.91^{\mathrm{a}}$ & $15.40 \pm 0.25^{\mathrm{a}}$ \\
A.C. $\left(\theta^{\circ}\right)$ & $36.46 \pm 0.23^{\mathrm{b}}$ & $36.57 \pm 0.12^{\mathrm{b}}$ & $65.46 \pm 4.10^{\mathrm{a}}$ & $61.57 \pm 4.64^{\mathrm{a}}$ \\
D.C. $(\mathrm{cm})$ & $8.47 \pm 0.06^{\mathrm{b}}$ & $8.44 \pm 0.02^{\mathrm{b}}$ & $11.34 \pm 0.40^{\mathrm{a}}$ & $11.72 \pm 0.27^{\mathrm{a}}$ \\
\hline
\end{tabular}

Note: different lowercase letters $\left({ }^{\mathrm{a}}\right.$ and $\left.{ }^{\mathrm{b}}\right)$ indicate significant differences $(p<0.05)$ between the values in the same row $(p<0.05)$.

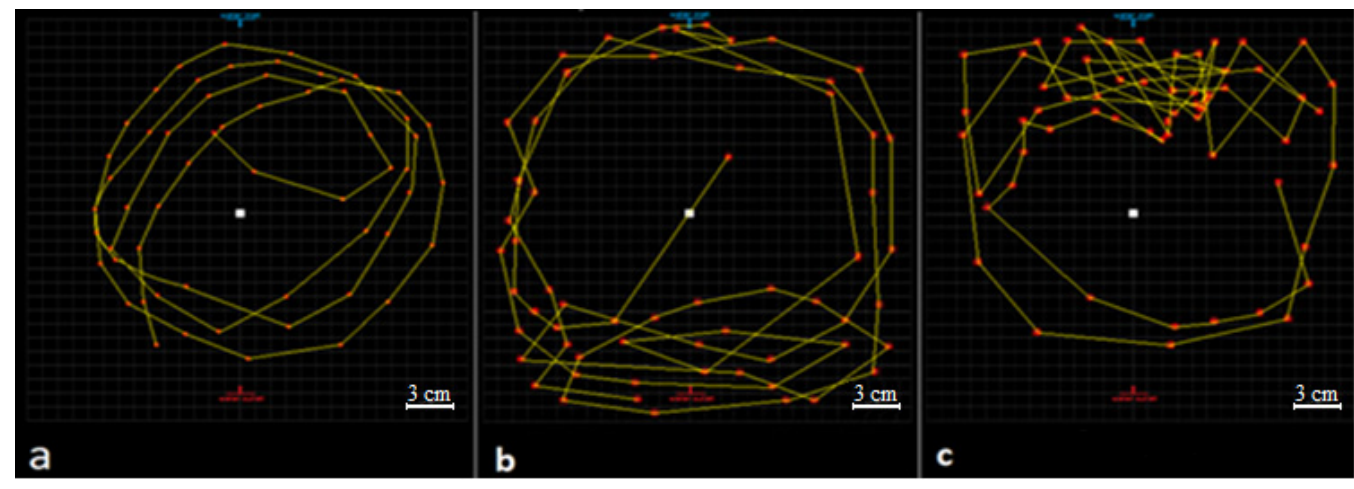

Figure 4. Fish swimming paths at different steps of the test $(1 \mathrm{~min})$ : (a) swimming path of the control group at 12th time point of step 1 (nominal concentrations of glyphosate suspension was $\left.0 \mathrm{~mL} \cdot \mathrm{L}^{-1}\right)$; (b) swimming path of glyphosate treatment (treatment group) at 12th time point of step 1 (nominal concentrations of glyphosate suspension was $63.03 \mathrm{~mL} \cdot \mathrm{L}^{-1}$ ); (c) swimming path of glyphosate treatment (treatment group) at 2nd time point of step 2 (nominal concentrations of glyphosate suspension was $63.03 \mathrm{~mL} \cdot \mathrm{L}^{-1}$ ). Paths measured with Digimizer (MedCalc Software, Version 4.6.1) on a Windows platform. The yellow lines are fish swimming path.

\subsubsection{Glyphosate Treatment}

During the behavioral test, no mortality was reported. There were significant correlations between swimming patterns parameters, the strongest correlation was between average swimming speed and total movement $(p<0.01)$; also, these two parameters had correlations with the fastest movement $(p<0.01)$, average angular changes of movement $(p<0.01)$, the average distance from the center $(p<0.01)$ and percent movement $(p<0.05)$. There were significant differences between the swimming pattern parameter of fish in the same concentration of different steps $(p<0.05)$. However, these differences were not seen at all concentrations (Figure 5).

Significant differences between swimming parameters of the glyphosate treatment and the control group were seen $(p<0.05)$. There were no significant differences between swimming parameters of the treatment group in step 1 and step 2 (Table 3). However, the fish were usually swimming near the water outlet of the test tank during step 1 , while they tended to be near the water inlet during step 2 (Figure 4). 


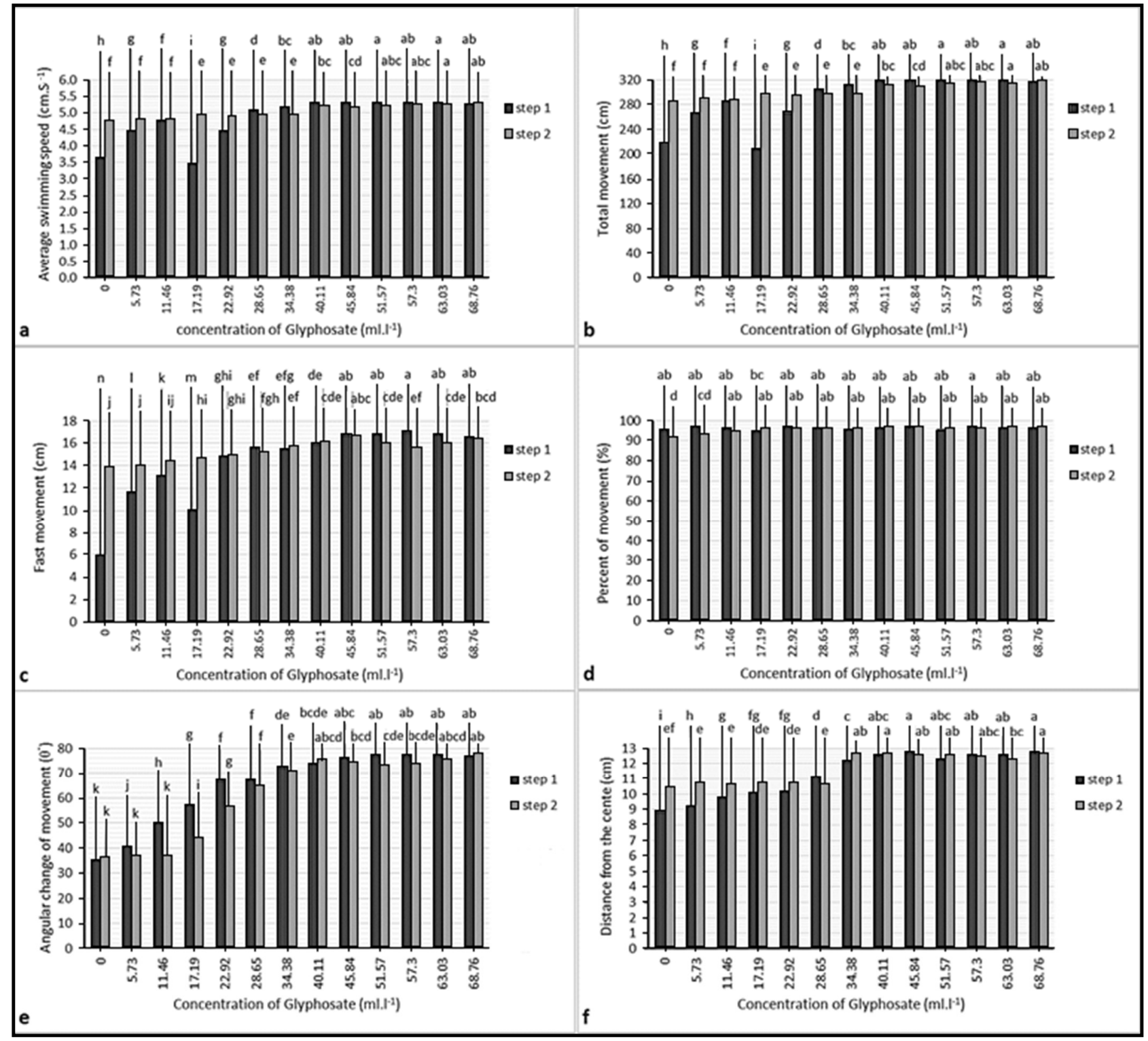

Figure 5. Parameters of swimming pattern of the fish in the control group: (a) average speed; (b) total movement; (c) fast movement; (d) percent of movement; (e) average angular change of movement; (f) distance from the center. Different lowercase letters ( $\mathrm{a}, \mathrm{b}, \mathrm{c}$ and else) indicate significant differences between values of the same color columns $(p<0.05)$.

The slopes of the diagrams of swimming parameters of fish (treatment group) were positive in step 1, but their values and slopes decreased and became negative in step 2, respectively. However, these reductions were not significant at the beginning of step 2, which coincides with the reduced concentrations of glyphosate (Figure 6). The average values of parameters of the treatment group were usually higher than those of the control group during the test, except for the average value of the percent of movement, which was lower than that of the control group at the end of step 2 (Figure $6 \mathrm{~d}$ ).

The total movement of fish after exposure to glyphosate was significantly increased, with a value lower than half of the test tank area $\left(660.185 \mathrm{~cm}^{2}\right)$. Fish that were exposed to sublethal and lethal concentrations of commercial formulation of glyphosate showed clinical signs, such as darkening of the skin, increasing movement of the operculum, anxiety, jumping out of the water and swimming near the surface. 


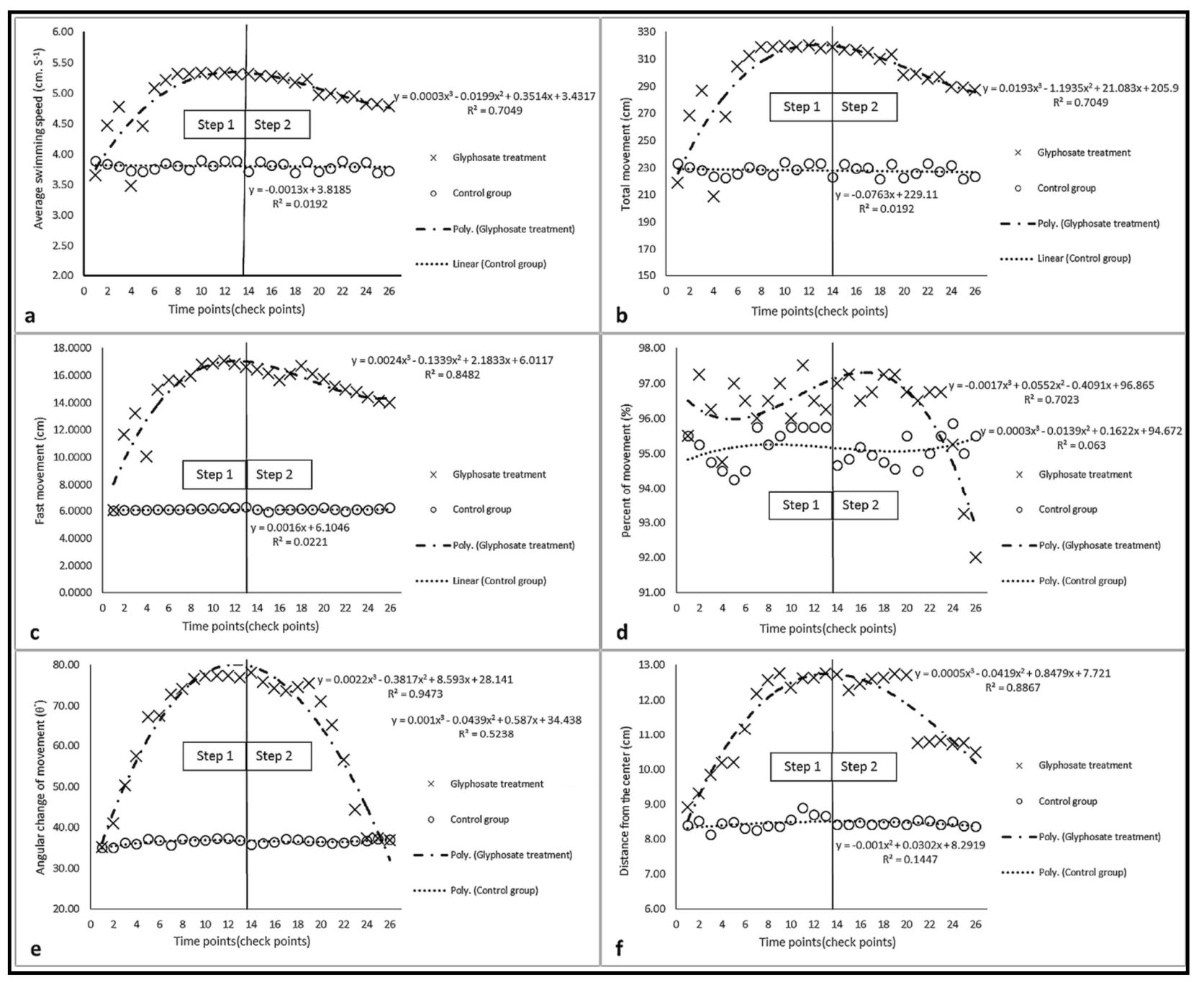

Figure 6. Diagrams of swimming parameters of fish in the test steps: (a) average speed; (b) total movement; (c) fast movement; (d) percent of movement; (e) average angular change of movement; (f) distance from the center.

\section{Discussion}

Contaminants can induce adverse physiological, behavioral and histopathological effects on aquatic organisms over time, depending on various factors, such as concentration and chemical structures [41-49]. Results of the present study showed that sublethal and lethal concentrations of commercial formulation of glyphosate significantly reduce the survival rate of fish, and can lead to significant tissue damages, such as hyperplasia of fish gills. The toxic effects of glyphosate were also seen and recognized through changes in the fish swimming patterns. Behavioral changes can further influence survival chances, reproductive success, nutrition and growth behaviors of the organism [35-38].

Vajargah et al. [19] stated that the $96 \mathrm{~h} \mathrm{LC}_{50}$ of glyphosate for fingerling common carp (Cyprinus carpio) was $92.71 \mathrm{~mL} \cdot \mathrm{L}^{-1}$ and this concentration was inconsistent with the result of the present study $\left(68.788 \mathrm{~mL} \cdot \mathrm{L}^{-1}\right)$. Nonetheless, all parameters in the present study were very similar to those in their study; differences were very small (nonsignificant) and were seen in the fish sizes. Body size is one of the intraspecific characteristics that could be related to differences in lethal concentration [37]. The average weight of fish in the present study and their study differed, and were $4.85 \pm 0.62$ and $7 \pm 0.8 \mathrm{~g}$, respectively. Thus, results of the $96 \mathrm{~h} \mathrm{LC}_{50}$ test are limited as they reflect laboratory conditions, but they can be useful to determine a range of lethal concentrations of pollutants.

Glyphosate $\left(\mathrm{C}_{3} \mathrm{H}_{8} \mathrm{NO}_{5} \mathrm{P} 41 \% \mathrm{SL}\right)$ acts on the activity of 5-enolpyruvylshikimate-3phosphate synthase (EPSP) and inhibits or impairs the synthesis of the aromatic amino 
acids in plant cells [21,23]. The results of the present study showed that glyphosate displayed significant toxic effects on common carp (Cyprinus carpio) as an aquatic nontarget organism, inducing histopathological damages [50]. The results of Neskovic et al. [51] showed that exposure to $5 \mathrm{mg} \cdot \mathrm{L}^{-1}$ of this pesticide can lead to epithelial hyperplasia, hypertrophy of chloride cells and lifting and rupture of the respiratory epithelium of carp gills. The results of their study were similar to ours. Tissue damages including hyperemia, hypertrophy, hyperplasia, secondary lamellar adhesion, hemorrhage and necrosis were found in gill samples of fish that were exposed to sublethal and lethal concentrations of glyphosate. There was a dose-dependent relationship between glyphosate concentrations and observed damages. Webster and Santos [52] stated that Roundup (common formulation of glyphosate) led to different variations in the complex interacting signaling pathways of juvenile female brown trout that control cellular stress response, particularly in apoptosis. In addition, the result of their study showed increased cell proliferation, cellular turnover and an up-regulation of metabolic processes.

After glyphosate exposure, the operculum movement (ventilatory frequency) and swimming activity of the fish was increased in a study conducted by Sinhorin [53]. Those results were in concordance to ours. In the present study, the swimming parameters, including average swimming speed, total movement, percent movement, fastest movement, average angular changes of movement and the average distance from the center, were changed and their values were significantly higher in the treatment group than in the control group. Moreover, the ventilatory frequency of fish was increased after glyphosate suspension exposure. Glyphosate has a toxic effect on the activity of the acetylcholine esterase enzyme and oxidative stress in common carp [54]. Results from the same authors showed the repression effect of glyphosate on acetylcholine esterase activity in the brain and muscles of fish and that its oxidative stress can lead to anxiety, increased fish metabolism, fatigue of fish and decreased energy levels. We showed that individuals exposed to glyphosate had clinical signs such as anxiety, and their percent movement significantly decreased at the end of step 2.

Behavior responses (such as swimming performance) as a tertiary level of physiological responses to a stressor can be used as a biomarker of stress [55]. Monitoring of the stressor factors in the environment is important [36], because these factors reduce organisms' fitness and survival chance [56-59]. The change of fish swimming patterns was observed in the present study. When the glyphosate suspension concentration was increased, the swimming speed increased, with frequent changes in the direction of swimming, and the fish tended to be near the water outlet; conversely, a decrease in the concentration of stressor caused the fish to swim near the water inlet.

\section{Conclusions}

Results of the given study clearly showed that glyphosate affects the swimming patterns of fish and can induce histopathological tissue damages. Some behavioral parameters such as swimming speed, average angular change of movement, the average distance of fish from the tank's center and the tendency of fish to be near the water inlet or outlet clearly point to anxiety in the fish and its tendency to escape contamination. Our results suggest that fish swimming parameters may be useful indicators of aquatic environments, and unlike some monitoring methods of pollutants effect (such as the $96 \mathrm{~h} \mathrm{LC}_{50}$ test) they do not require killing fish, histopathological processes and fish catching. However, the data of the present study were limited to laboratory conditions and further studies are required. Swimming patterns were shown to be a promising method for collecting clinical signs of fish as a response to environmental stressors (such as pollutants).

Author Contributions: A.M.Y. and M.F.V. were responsible for conceptualization, conducted most of the experiments and wrote the original draft. A.H. and C.F. supervised the experiments and offered assistance during the tests. M.M.G. provided the resources, including working space and equipment. M.D.P. provided supervision and contributed to the writing (review and editing) of the manuscript. All authors have read and agreed to the published version of the manuscript. 
Funding: This research did not receive any specific grant from funding agencies in the public, commercial, or not-for-profit sectors.

Institutional Review Board Statement: The protocol of the study was according to guidelines issued by the Gorgan University of Agricultural Sciences and Natural Resources Research Ethics Committee No. IR-GAUEC207s-2020.

Informed Consent Statement: Not applicable.

Data Availability Statement: The data presented in this study are available on request from the corresponding author. The data are not publicly available due to proprietary nature of Iranian Ministry of Science Research and Technology.

Acknowledgments: The authors thank all the people who helped them to complete this study.

Conflicts of Interest: The authors declare that they have no conflict of interest.

\section{References}

1. Taiz, L. Agriculture, plant physiology, and human population growth: Past, present, and future. Theor. Exp. Plant. Physiol. 2013, 25, 167-181. [CrossRef]

2. World Bank. World Development Report 2008: Agriculture for Development; The World Bank: Washington, DC, USA, 2007.

3. Cleland, J. World Population Growth; Past, Present and Future. Environ. Resour. Econ. 2013, 55, 543-554. [CrossRef]

4. Pinstrup-Andersen, P. Food and Agricultural Policy for a Globalizing World: Preparing for the Future. Am. J. Agric. Econ. 2002, 84, 1201-1214. [CrossRef]

5. Oerke, E.C. Crop losses to pests. J. Agr. Sci. 2005, 144, 31-43. [CrossRef]

6. Atreya, K.; Sitaula, B.K.; Bajracharya, R.M. Pesticide use in agriculture: The philosophy, complexities and opportunities. Sci. Res. Essay 2012, 7, 2168-2173.

7. Raven, P.H.; Berg, L.R.; Hassenzahl, D.M. Environment, 6th ed.; John Wiley and Sons Inc.: New York, NY, USA, 2008; 672p.

8. Vajargah, F.; Yalsuyi, M.A.; Hedayati, A.; Faggio, C. Histopathological lesions and toxicity in common carp (Cyprinus carpio L. 1758) induced by copper nanoparticles. Micro. Res. Tech. 2018, 81, 724-729. [CrossRef]

9. Popp, J.; Pető, K.; Nagy, J. Pesticide productivity and food security. A review. Agron. Sustain. Dev. 2012, 33, 243-255. [CrossRef]

10. Pimentel, D.; Burgess, M. Small amounts of pesticides reaching target insects. Environ. Dev. Sustain. 2011, 14, 1-2. [CrossRef]

11. Yalsuyi, A.M.; Hedayati, A.; Vajargah, M.F.; Mousavi-Sabet, H. Examining the toxicity of Cadmium chloride in common carp (Cyprinus carpio) and Goldfish (Carassius auratus). J. Environ. Treat. Tech. 2017, 5, 83-86.

12. Vajargah, M.F.; Yalsuyi, A.M.; Sattari, M.; Prokić, M.D.; Faggio, C. Effects of Copper oxide nanoparticles (CuO-NPs) on parturition time, survival rate and reproductive success of Guppy fish, Poecilia reticulata. J. Cluster Sci. 2020, 31, 499-506. [CrossRef]

13. Burgos Aceves, M.A.; Migliaccio, V.; Lepretti, M.; Paolella, G.; di Gregorio, I.; Penna, S.; Faggio, C.; Lionetti, L. 1,1,1-trichloro2,2-bis (p-chlorophenyl)-ethane (DDT) and 1,1-Dichloro-2,2-bis (p, p'-chlorophenyl) ethylene (DDE) as endocrine disruptors in human and wildlife: A possible implication of mitochondria. Environ. Toxicol. Pharmacol. 2021, 87, 103684. [CrossRef] [PubMed]

14. Vajargah, F.M.; Mohsenpour, R.; Yalsuyi, A.M.; Galangash, M.M.; Faggio, C. Evaluation of histopathological effect of Roach (Rutilus rutiluscaspicus) in exposure to sub-lethal concentrations of Abamectin. Water Air Soil Pollut. 2021, 232, 188. [CrossRef]

15. Faria, M.; Prats, E.; Ramírez, J.R.R.; Bellot, M.; Bedrossiantz, J.; Pagano, M.; Valls, A.; Gomez-Canela, C.; Porta, J.M.; Mestres, J.; et al. Androgenic activation, impairment of the monoaminergic system and altered behavior in zebrafish larvae exposed to environmental concentrations of fenitrothion. Sci. Total. Environ. 2021, 775, 145671. [CrossRef] [PubMed]

16. Evans, S.C.; Shaw, E.M.; Rypstra, A.L. Exposure to a glyphosate-based herbicide affects agrobiont predatory arthropod behaviour and long-term survival. Ecotoxicology 2010, 19, 1249-1257. [CrossRef]

17. Yalsuyi, A.M.; Vajargah, M.F. Acute toxicity of silver nanoparticles in Roach (Rutilus rutilus) and Goldfish (Carassius auratus). J. Environ. Treat. Tech. 2017, 5, 1-4.

18. Hedayati, A.; Yalsuyi, A.M.; Vajargah, M.F. Acute toxicity test as a method to assessment toxicity of pollutants. Ann. Aquacult. Res. 2017, 4, 1036.

19. Vajargah, M.F.; Yalsuyi, A.M.; Sattari, M.; Hedayati, A. Acute toxicity effect of glyphosate on survival rate of common carp, Cyprinus carpio. Environ. Heal. Eng. Manag. 2018, 5, 61-66. [CrossRef]

20. Oliveira, J.L.; Campos, E.; Bakshi, M.; Abhilash, P.; Fraceto, L. Application of nanotechnology for the encapsulation of botanical insecticides for sustainable agriculture: Prospects and promises. Biotechnol. Adv. 2014, 32, 1550-1561. [CrossRef]

21. Poiger, T.; Buerge, I.J.; Bächli, A.; Müller, M.D.; Balmer, M. Occurrence of the herbicide glyphosate and its metabolite AMPA in surface waters in Switzerland determined with on-line solid phase extraction LC-MS/MS. Environ. Sci. Pollut. Res. 2016, 24, 1588-1596. [CrossRef] [PubMed]

22. Benbrook, C.M. Trends in glyphosate herbicide use in the United States and globally. Environ. Sci. Eur. 2016, 28, 1-15. [CrossRef] [PubMed] 
23. Myers, J.P.; Antoniou, M.N.; Blumberg, B.; Carroll, L.; Colborn, T.; Everett, L.G.; Hansen, M.; Landrigan, P.J.; Lanphear, B.P.; Mesnage, R.; et al. Concerns over use of glyphosate-based herbicides and risks associated with exposures: A consensus statement. Environ. Heal. 2016, 15, 1-13. [CrossRef]

24. Chorehi, M.M.; Ghaffari, H.; Hossaini, S.A.; Niazie, E.H.N.; Vajargah, M.F.; Hedayati, A. Acute toxicity of Diazinon to the Caspian vimba, Vimba vimba persa (Cypriniformes: Cyprinidae). Inter. J. Aqua. Biol. 2013, 1, 254-257.

25. Vajargah, M.F.; Yalsuyi, A.M.; Hedayati, A. Acute toxicity of povidone-iodine (Betadine) in common carp (Cyprinus carpio L. 1758). Pollution 2017, 3, 589-593.

26. Vajargah, M.F.; Imanpoor, M.R.; Shabani, A.; Hedayati, A.; Faggio, C. Effect of long-term exposure of silver nanoparticles on growth indices, hematological and biochemical parameters and gonad histology of male Goldfish (Carassius auratus gibelio). Micro. Res. Tech. 2019, 82, 1224-1230. [CrossRef] [PubMed]

27. Larras, F.; Montuelle, B.; Bouchez, A. Assessment of toxicity thresholds in aquatic environments: Does benthic growth of diatoms affect their exposure and sensitivity to herbicides? Sci. Total. Environ. 2013, 463-464, 469-477. [CrossRef] [PubMed]

28. Gill, J.P.K.; Sethi, N.; Mohan, A.; Datta, S.; Girdhar, M. Glyphosate toxicity for animals. Environ. Chem. Lett. 2017, 16, 401-426. [CrossRef]

29. Loro, V.L.; Glusczak, L.; Moraes, B.S.; Leal, C.A.M.; Menezes, C.; Murussi, C.R.; Leitemperger, J.W.; Schetinger, M.R.C.; Morsch, V.M. Glyphosate-based herbicide affects biochemical parameters in Rhamdia quelen (Quoy \& Gaimard, 1824 and) Leporinus obtusidens (Valenciennes, 1837). Neotropical Ichthyol. 2015, 13, 229-236. [CrossRef]

30. Tian, Y.-S.; Xu, J.; Xing, X.-J.; Zhao, W.; Fu, X.-Y.; Peng, R.-H.; Yao, Q.-H. Improved glyphosate resistance of 5-enolpyruvylshikimate3-phosphate synthase from Vitis vinifera in transgenic Arabidopsis and rice by DNA shuffling. Mol. Breed. 2015, 35, 1-11. [CrossRef]

31. Tohge, T.; Watanabe, M.; Hoefgen, R.; Fernie, A.R. Shikimate and Phenylalanine Biosynthesis in the Green Lineage. Front. Plant. Sci. 2013, 4, 62. [CrossRef]

32. Souza, E.L.C.; Foloni, L.L.; Filho, J.T.; Velini, E.D.; Siono, L.M.; Silva, J.R.M. Half-Life of Glyphosate on the Control of Water Hyacinths in Water Tanks. J. Water Resour. Prot. 2017, 9, 470-481. [CrossRef]

33. Vajargah, M.F.; Namin, J.I.; Mohsenpour, R.; Yalsuyi, A.M.; Prokić, M.D.; Faggio, C. Histological effects of sublethal concentrations of insecticide Lindane on intestinal tissue of grass carp (Ctenopharyngodon idella). Veter- Res. Commun. 2021, 1-8. [CrossRef]

34. Kang, I.J.; Moroishi, J.; Nakamura, A.; Nagafuchi, K.; Kim, S.G.; Oshima, Y. Biological Monitoring for Detection of Toxic Chemicals in Water by the Swimming Behavior of Small Freshwater Fish. J. Fac. Agric. Kyushu Univ. 2009, 54, 209-214. [CrossRef]

35. Huang, Y.; Zhang, J.; Han, X.; Huang, T. The use of zebra fish (Danio rerio) behavioral responses in identifying sublethal exposures to Deltamethrin. Inter. J. Environ. Res. Public Health 2014, 11, 3650-3660. [CrossRef]

36. Kane, A.S.; Salierno, J.D.; Gipson, G.T.; Molteno, T.C.; Hunter, C. A video-based movement analysis system to quantify behavioral stress responses of fish. Water Res. 2004, 38, 3993-4001. [CrossRef] [PubMed]

37. Saglio, P.; Trijasse, S. Behavioral responses to atrazine and diuron in goldfish. Arch. Environ. Contam. Toxicol. 1998, 35, 484-491. [CrossRef] [PubMed]

38. Vogel, C.; Grillitsch, B.; Wytek, R.; Spieser, O.H.; Scholz, W. Qualification of spontaneous undirected locomotor behavior of fish for sublethal toxicity testing. Part I. Variability of measurement parameters under general test conditions. Environ. Toxicol. Chem. 1999, 18, 2736-2742. [CrossRef]

39. Zhou, T.; Weis, J.S. Swimming behavior and predator avoidance in three populations of Fudulus heteroclitus larvae after embryonic exposure and/or larval exposure to methylmercury. Aquat Tox 1998, 43, 131-148. [CrossRef]

40. Yalsuyi, A.M.; Hajimoradloo, A.; Ghorbani, R.; Jafari, V.-A.; Prokić, M.D.; Faggio, C. Behavior evaluation of rainbow trout (Oncorhynchus mykiss) following temperature and ammonia alterations. Environ. Toxicol. Pharmacol. 2021, 86, 103648. [CrossRef]

41. Chromcova, L.; Blahova, J.; Zivna, D.; Plhalova, L.; Di Tocco, F.C.; Divisova, L.; Prokeš, M.; Faggio, C.; Tichy, F.; Svobodová, Z. NeemAzal T/S - toxicity to early-life stages of common carp (Cyprinus carpio L.). Vet. Med. 2016, 60, 23-30. [CrossRef]

42. Hodkovicova, N.; Chmelova, L.; Sehonova, P.; Blahova, J.; Doubkova, V.; Plhalova, L.; Fiorino, E.; Vojtek, L.; Vicenova, M.; Siroka, Z.; et al. The effects of a therapeutic formalin bath on selected immunological and oxidative stress parameters in common carp (Cyprinus carpio). Sci. Total. Environ. 2018, 653, 1120-1127. [CrossRef]

43. Hodkovicova, N.; Enevova, V.; Cahova, J.; Blahova, J.; Siroka, Z.; Plhalova, L.; Doubkova, V.; Marsalek, P.; Franc, A.; Fiorino, E.; et al. Could the musk compound tonalide affect physiological functions and act as an endocrine disruptor in rainbow trout? Physiol. Res. 2020, 69, 595-606. [CrossRef]

44. Aliko, V.; Mehmeti, E.; Qirjo, M.; Faggio, C. 'Drink and sleep like a fish': Goldfish as a behavior model to study pharmaceutical effects in freshwater ecosystems. J. Biol. Res. 2019, 92. [CrossRef]

45. Stara, A.; Bellinvia, R.; Velisek, J.; Strouhova, A.; Kouba, A.; Faggio, C. Acute exposure of neonicotinoid pesticide on common yabby (Cherax destructor). Sci. Total Environ. 2019, 665, 718-723. [CrossRef]

46. Stara, A.; Kubec, J.; Zuskova, E.; Buric, M.; Faggio, C.; Kouba, A.; Velisek, J. Effects of S-metolachlor and its degradation product metolachlor OA on marbled crayfish (Procambarus virginalis). Chemosphere 2019, 224, 616-625. [CrossRef] [PubMed]

47. Stara, A.; Pagano, M.; Capillo, G.; Fabrello, J.; Sandova, M.; Vazzana, I.; Zuskova, E.; Velisek, J.; Matozzo, V.; Faggio, C. Assessing the effects of neonicotinoid insecticide on the bivalve mollusc Mytilus galloprovincialis. Sci. Total. Environ. 2019, 700, 134914. [CrossRef] [PubMed] 
48. Pagano, M.; Stara, A.; Aliko, V.; Faggio, C. Impact of Neonicotinoids to Aquatic Invertebrates-In Vitro Studies on Mytilus galloprovincialis: A Review. J. Marine Sci. Engine. 2020, 8, 801. [CrossRef]

49. Sula, E.; Aliko, V.; Barceló, D.; Faggio, C. Combined effects of moderate hypoxia, pesticide and PCBs upon Crucian Carp fish, Carassius carrasius, from a freshwater lake-in situ ecophysiological approach. Aquat. Toxicol. 2020, 228, 105644. [CrossRef] [PubMed]

50. Fiorino, E.; Sehonova, P.; Plhalova, L.; Blahova, J.; Svobodova, Z.; Faggio, C. Effects of glyphosate on early life stages: Comparison between Cyprinus carpio and Danio rerio. Environ. Sci. Pollut. Res. 2018, 25, 8542-8549. [CrossRef] [PubMed]

51. Nešković, N.K.; Poleksić, V.; Elezović, I.; Karan, V.; Budimir, M. Biochemical and Histopathological Effects of Glyphosate on Carp, Cyprinus carpio L. Bull. Environ. Contam. Toxicol. 1996, 56, 295-302. [CrossRef]

52. Webster, T.M.U.; Santos, E.M. Global transcriptomic profiling demonstrates induction of oxidative stress and of compensatory cellular stress responses in brown trout exposed to glyphosate and Roundup. BMC Genom. 2015, 16, 1-14. [CrossRef]

53. Sinhorin, V.D.G.; Sinhorin, A.P.; Teixeira, J.M.S.; Miléski, K.M.L.; Hansen, P.C.; Moeller, P.R.; Moreira, P.S.A.; Baviera, A.M.; Loro, V. Metabolic and Behavior Changes in Surubim Acutely Exposed to a Glyphosate-Based Herbicide. Arch. Environ. Contam. Toxicol. 2014, 67, 659-667. [CrossRef] [PubMed]

54. Cattaneo, R.; Clasen, B.; Loro, V.L.; Menezes, C.; Pretto, A.; Baldisserotto, B.; Santi, A.; Avila, L. Toxicological Responses of Cyprinus carpio Exposed to a Commercial Formulation Containing Glyphosate. Bull. Environ. Contam. Toxicol. 2011, 87, 597-602. [CrossRef] [PubMed]

55. Portz, D.E.; Woodley, C.M.; Cech, J.J. Stress-associated impacts of short-term holding on fishes. Rev. Fish. Biol. Fish. 2006, 16, 125-170. [CrossRef]

56. Hedayati, A.; Vajargah, M.F.; Yalsuyi, A.M.; Abarghoei, S.; Hajiahmadyan, M. Acute toxicity test of pesticide abamectin on common carp (Cyprinus carpio). J. Coast. Life Med. 2014, 2, 841-844.

57. Paoletti, M.G.; Pimentel, D. Environmental Risks of Pesticides Versus Genetic Engineering for Agricultural Pest Control. J. Agric. Environ. Ethic 2000, 12, 279-303. [CrossRef]

58. Vajargah, M.F.; Hedayati, A. Acute Toxicity of Butachlor to Rutilus rutilus caspicus and Sander lucioperca in Vivo Condition. Transylv. Rev. Syst. Ecol. Res. 2017, 19, 85-92. [CrossRef]

59. Vajargah, M.F.; Hossaini, S.A.; Niazie, E.H.N.; Hedayati, A.; Vesaghi, M.J. Acute toxicity of two pesticides Diazinon and Deltamethrin on Tench (Tinca tinca) larvae and fingerling. Inter. J. Aquat. Biol. 2013, 1, 138-142. 